\title{
Conceptual models of forest dynamics in environmental education and management: keep it as simple as possible, but no simpler
}

Timo Kuuluvainen (D)

\begin{abstract}
Background: Conceptual models of forest dynamics are powerful cognitive tools, which are indispensable for communicating ecological ideas and knowledge, and in developing strategic approaches and setting targets for forest conservation, restoration and sustainable management. Forest development through time is conventionally described as a directional, or "linear", and predictable sequence of stages from "bare ground" to old forest representing the "climax-state". However, this simple view is incompatible with the current knowledge and understanding of intrinsic variability of forest dynamics.

Hypothesis: Overly simple conceptual models of forest dynamics easily become transformed into biased mental models of how forests naturally develop and what kind of structures they display. To be able to communicate the essential features and diversity of forest dynamics, comprehensive conceptual models are needed. For this end, Kuuluvainen (2009) suggested a relatively simple conceptual model of forest dynamics, which separates three major modes of forest dynamics, and incorporates state changes and transitions between the forest dynamics modes depending on changes in disturbance regime.

Conclusions: Conceptual models of forest dynamics should be comprehensive enough to incorporate both longterm directional change and short-term cyclic forest dynamics, as well as transitions from one dynamics mode to another depending on changes in the driving disturbance regime type. Models that capture such essential features of forest dynamics are indispensable for educational purposes, in setting reference conditions and in developing methods in forest conservation, restoration and ecosystem management.
\end{abstract}

Keywords: Natural forest, Forest succession, Forest disturbance, Forest age structure, Forest conservation, Forest restoration, Sustainable management

\section{Review}

Much of the persistent controversy surrounding succession stems from the different starting points or pioneer stages following varied kinds and degrees of disturbance, from which the seral sequence begins.

Robert McIntosh 1981

Correspondence: Timo.Kuuluvainen@helsinki.fi

Department of Forest Sciences, University of Helsinki, P.O. Box 27, Helsinki FIN-00014, Finland
Since the formulation of the first concise scientific theory of plant succession in the early $20^{\text {th }}$ century by Frederick Clements (1916), forest succession has conventionally been described as an orderly, directional and well predictable development of vegetation community change through time (McIntosh 1981; Peet 1981; but see Cowles 1911). Similar to the seral stages in Clements' theory, successional development of forests has been divided into more or less arbitrarily defined developmental stages (Bormann and Likens 1979; Oliver 1980). Perhaps the simplest and most widely used and well known is the classification of Oliver (1980), dividing forest stand

\section{Springer Open}

(c) 2016 The Author(s). Open Access This article is distributed under the terms of the Creative Commons Attribution 4.0 International License (http://creativecommons.org/licenses/by/4.0/), which permits unrestricted use, distribution, and reproduction in any medium, provided you give appropriate credit to the original author(s) and the source, provide a link to the Creative Commons license, and indicate if changes were made. 
succession into four stages: stand initiation, stem exclusion, understorey re-initiation and old-growth stages. Over time, several alternative ways to divide stand succession into contiguous phases have been proposed (for a review see Franklin et al. 2002).

Although many of the elements of Clements' original theory, such as the existence of clearly separable contiguous seral or successional stages and the idea of a static successional end point, the climatic climax, have by and large been abandoned (McIntosh 1981; Pickett et al. 2008; Christensen 2014), the directional "linear" representation of forest succession has been persistent, even in the leading ecological textbooks (for example Begon et al. 2006, p. 479-488). Although recent studies have put more emphasis on the effect of disturbance characteristics and legacies on forest dynamics, and variability of successional pathways (Glenn-Lewin and van der Maarel 1992; Pickett et al. 2008; Larsen and Chen 2011; Burton 2013), directional representations of forest succession have until recently been dominant in research literature as well (e.g. Franklin et al. 2002; Donato et al. 2012).

The simplified conceptualization of forest succession as a directional deterministic process, starting from "bare ground" has been particularly persistent concerning the boreal forest, where stand-replacing fire has traditionally been regarded as the 'norm disturbance' (Fig. 1, Payette 1992; Bergeron et al. 2002). However, the accumulated body of research evidence indicates that this model is not able to incorporate the observed variability of disturbance-successions cycles documented in unmanaged forests in the circumboreal zone (Kneeshaw et al. 2011; Kuuluvainen and Aakala 2011; Burton 2013; Bergeron and Fenton 2012). Use of excessively simple and therefore unrealistic conceptual models in education and management can easily lead to distorted views of how forest ecosystems develop and what kind of structural variation they naturally display. Such biased models, if adopted by ecologists, foresters and resource managers, may have serious and adverse consequences for efforts aiming at conservation, restoration and sustainable management of forests ecosystems.
In forest conservation and restoration, simple conceptual models of forest dynamics based on outdated information can lead to biased definitions of natural reference conditions (natural range of variation), which are crucial in setting goals and choosing management methods (Landres et al. 1999; Halme et al. 2013). In forest management, simplified conceptual models can lead to "knowledge lock-ins", where outdated views of intrinsic forest structure and dynamics are used as a basis and framework of management actions (Moen et al. 2014). This can in turn lead to failure in attaining ecological sustainability goals because the targeted habitat conditions deviate much more from natural reference conditions than realized. For example, conventional even-aged "command-and-control" management approaches may have been argued to be "nature-based" (Holling and Meffe 1996; Moen et al. 2014), although they actually differ drastically from natural forest dynamics (Gauthier et al. 2009; Kuuluvainen 2009; Puettmann et al. 2008). Therefore, realistic conceptual models are indispensable tools for communicating up-to-date ecological knowledge concerning intrinsic forest dynamics, for efficient forest conservation and restoration and for developing novel strategies of sustainable forest ecosystem management (Gauthier et al. 2009; Halme et al. 2013).

In this paper, I review and visualize the main types of suggested conceptual models of forest dynamics and discuss and compare their basic properties. Based on this, I present a relatively simple but comprehensive conceptual model, suggested by Kuuluvainen (2009) for boreal forests, which incorporates both long-term directional and shorter-term cyclic forest dynamics, as well as transitions from one forest dynamics mode to another depending on the characteristics of the driving disturbance regime. Finally, I discuss the stand and landscape level implications of the reviewed conceptual models for forest restoration and ecosystem-based management.

\section{From directional to cyclic conceptual models of forest dynamics}

Over decades, simple directional or "linear" deterministic representation of forest dynamics, starting from 'bare ground' and ending in static "climax" forest, has been

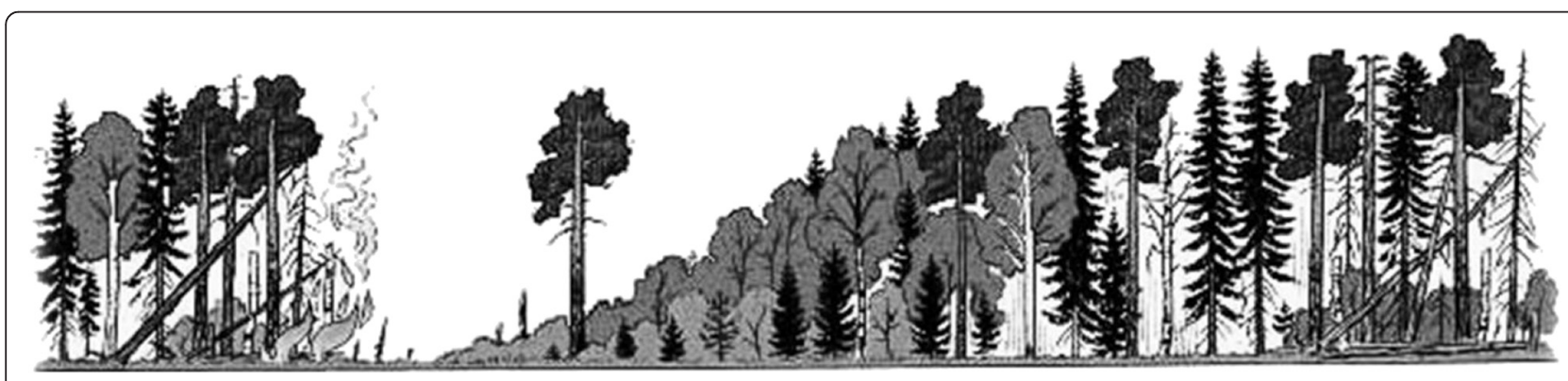

Fig. 1 An illustration of classical directional forest succession of the boreal forest after stand-replacing fire 


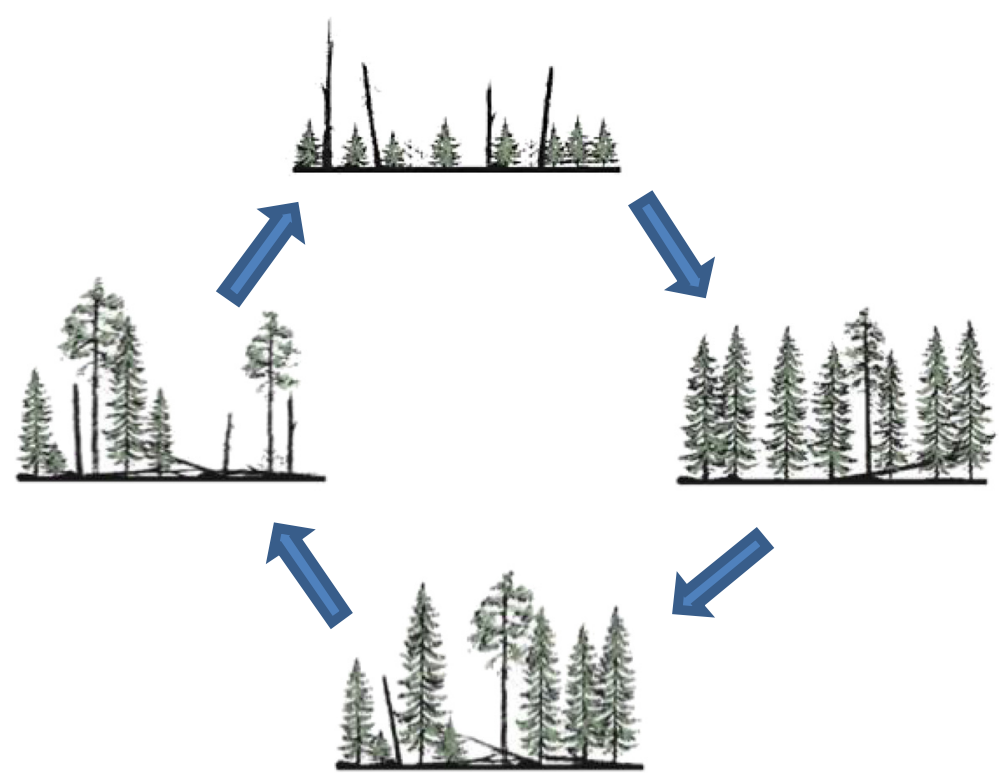

Fig. 2 Illustration of the mosaic cycle concept, where different successional stages of forest development are expressed as a cycle. The scale of dynamics can range from stand-replacement to fine scale gap dynamics (Remmert 1991)

the de facto conceptual model of boreal forest dynamics (Fig. 1; Payette 1992; Johnson 1996). However, from 1990s onwards it has become increasingly evident from the accumulated body of research results, that forest dynamics is a much more diverse phenomenon. It has been shown that in addition to stand-replacing disturbances, small scale and intermediate-severity disturbances and associated forest dynamics (gap, patch and cohort dynamics) are prevalent phenomena especially in old forests across the boreal biome (e.g. Kuuluvainen 1994; McCarthy 2001; Shorohova et al. 2009; Kneeshaw et al. 2011; Kuuluvainen and Aakala 2011). This, accompanied by the revelation of the overall ecological importance of disturbances in forest ecosystems globally (Sprugel and Bormann 1981; Pickett and White 1985), created a pressure to revise the established simple directional conceptual model of forest dynamics. The answer was to develop new conceptual models that involved disturbances and cyclic representations of forest dynamics (Bormann and Likens 1979). A good example is provided by the mosaic-cycle concept which has been applied to temperate and mountain forests of Central Europe (Fig. 2, Remmert 1991; Podlaski 2008).

Concerning boreal forests, this development led to an adoption of a simple dichotomic concept of two distinct and in space and time alternating cyclic modes of forest dynamics (Fig. 3). The first one is the 'large cycle' mode driven by infrequent and often large-scale stand-replacing disturbances, such as caused by high-severity fires or windstorms, initiating more or less even-aged forest development. Such disturbances have also been called Large
Infrequent Disturbances (LIDs, Turner and Dale 1998). The second forest dynamics mode described was the 'small cycle', which was described to develop in latesuccessional forests and consist of senescence-related fine scale tree mortality and regeneration dynamics in gaps (Fig. 3; Forcier 1975; Seymour et al. 2002). Related ecological concepts are those of gap phase dynamics (Pickett and White 1986) and the shifting-mosaic steady state (Bormann and Likens 1979), which emphasize the spatial dimension of forest dynamics.

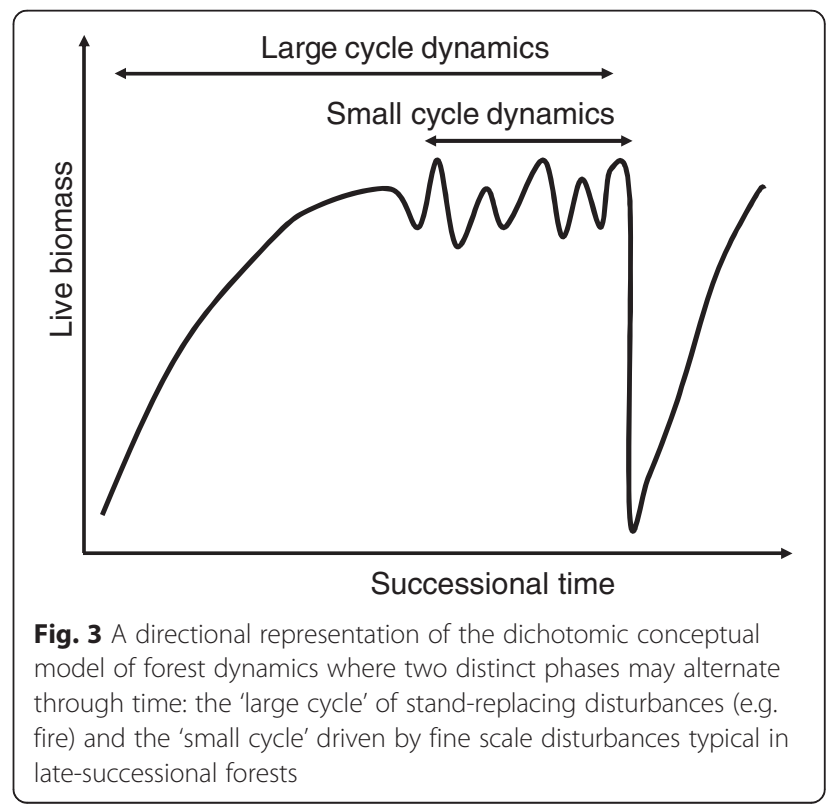


This kind of dichotomic conceptual model could be applicable to old-growth dominated landscapes driven predominantly by small scale gap dynamics, which are punctuated with relatively rare but severe fires or storms (Syrjänen et al. 1994; Seymour et al. 2002). In such a case the forest landscape would consist of a combination of two very different kinds of dynamics, which are spatially and temporally separated: old gap dynamic forest (small cycle) and patches of younger even-aged forest regenerating after stand-replacing disturbance (large cycle) (Sirén 1955; Kuuluvainen et al. 1998).

Worrall et al. (2005) suggested, based on their studies on Picea-Abies forests in New Hampshire, that the two types of dynamics are not spatio-temporally distinct but they can operate as mixed both in space and time. The small scale gap phase cycles would operate as nested dynamics within larger scale infrequent non-stand-replacing disturbance cycles that occur at landscape scale. This kind of dynamics was also described in Sweden by Fraver et al. (2008) and by Kuuluvainen et al. (2014) in the primeval forest of the Archangelsk region in NW Russia. In this "nested bicycle" model of Worrall et al. (2005), the large cycle is driven by a disturbance that is partial and selective affecting only dominant trees (e.g. wind storms) or one species (e.g. host-specificity of fungi or insects).

The multi-cohort model of boreal forest dynamics was developed in eastern boreal Canada. It aims to describe forest dynamics driven by stand-replacing fire in coniferous and mixed species forests (Bergeron et al. 2002; Bergeron and Fenton 2012). It divides the directional successional development following stand-replacing disturbance (fire) into separate successional stages or seres, which are called structural cohorts (Fig. 4). Here the term cohort does not refer to tree age cohorts, as usual, but to the contiguous stages of forest structure in succession, similar to those presented by Oliver (1981). In addition to classical directional succession, in late successional stages forest dynamics can be driven by cyclic small scale gap dynamics (Fig. 4). Thus the multi-cohort model incorporates the large vs. small cycle idea. Belleau et al. (2011) refined the multi-cohort approach further to include the effect of fire severity (i.e. proportion of living plant biomass destroyed) on tree species composition in successional development.

The multi-cohort model has also been suggested as a conceptual basis for forest management that aims to emulate natural forest disturbances and structures, as driven by fire, both at stand and landscape scale. The structural cohorts and their dynamics are emulated using adapted silvicultural methods such as selection and group cutting, and by leaving retention trees. The landscape level target proportions and spatial pattern of different structural cohorts can be derived for example from historical disturbance reconstructions of the landscapes (Bergeron et al. 2002). It is obvious that the success of this approach in creating a functional "coarse filter" habitat mosaic depends on how realistic is the description of forest development and how well it can be emulated in management.

The Panarchy concept provides perhaps the most general cyclic representation for multi- and cross-scale ecosystem dynamics (Holling 2001). This model, which is not restricted to forests, can be used to explain how ecosystems maintain their biodiversity and resilience through cyclic cross-scale dynamics of change and rearrangement over time (Gunderson and Holling 2002). In the Panarchy cycle, disturbances and subsequent successions, leading to a reorganization of the ecosystem through colonization and early development, are crucial stages of the cycle allowing novel species and genotype combinations to appear and their viability to be tested against continuously changing biota and environmental conditions. This process, fostering resilience and adaptive capacity of ecosystems, can be seen as connected to recent findings concerning eco-evolutionary dynamics (Schoener 2011). However, being very general or even metaphorical, the Panarchy concept in its basic form does not specifically deal with details of ecosystem

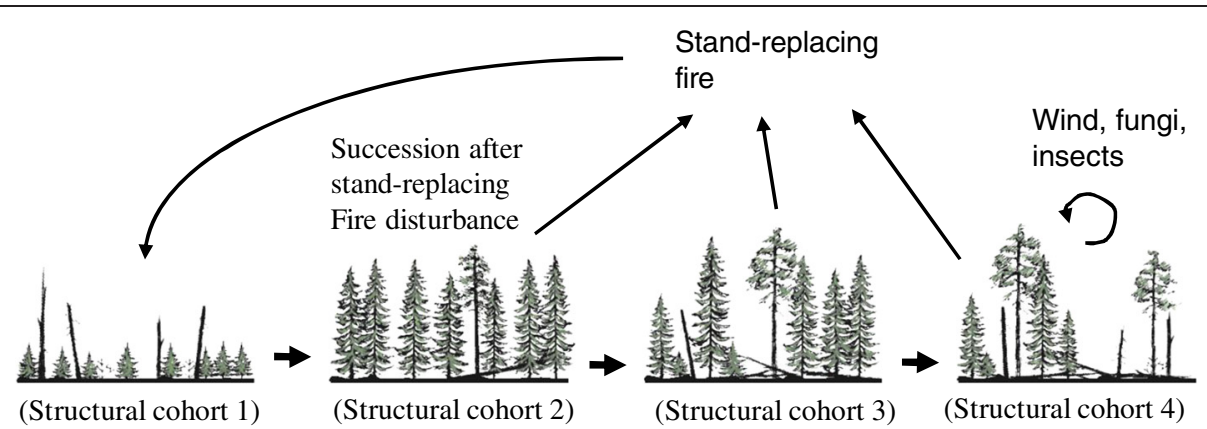

Fig. 4 Illustration of the multi-cohort model of forest dynamics, where directional forest development after stand-replacing disturbance is represented as structural cohorts (1-4). In late-successional stages forest structure can perpetuate itself through fine scale gap dynamics driven by wind, fungi and insect disturbances. Stand-replacing disturbance can reset forest development to "bare ground" from any developmental stage 
succession or variability in disturbance characteristics (Drever et al. 2006). However, the model adequately emphasizes the ecological importance of disturbance and subsequent ecosystem reorganization, as well as long term cyclic ecosystem dynamics, for ecosystem resiliency and adaptive capasity.

One obvious shortcoming of the reviewed directional, as well as simple cyclic models of forest dynamics is that, although they acknowledge disturbance as part of the forest dynamics, they only pay limited attention to the crucial role of disturbance properties on ecosystem dynamics (but see Belleau et al. 2011). Here especially the variability of disturbance quality and severity, and the resulting diversity of disturbance legacies, as well as the existing species pool of the surrounding landscape, are known to be crucial factors affecting forest regeneration dynamics, successional pathways and reorganization of the whole biotic community after disturbance (e.g. Bengtsson et al. 2003; Worrall et al. 2005; Johnstone and Chapin 2006; Pickett et al. 2008).

\section{Towards a comprehensive conceptual model of boreal forest dynamics}

It has been wisely stated that things should be made as simple as possible, but no simpler (the Einstein principle). This also applies to conceptual and visual descriptions of forest dynamics. A crucial question in formulating a comprehensive conceptual model for forest dynamics is how to incorporate the inherent complexity and variability of forest structural dynamics in sufficient detail, but at the same time simplify the phenomenon sufficiently to facilitate efficient communication of the main ideas (Bunnell and Johnson 1999). In boreal forest management this "complexity challenge" is related to the accumulating body of research results documenting the prevalence of small scale and partial disturbances driving the development of variable and heterogeneous stand structures (Kuuluvainen 2009; Kuuluvainen et al. 2015). This makes it necessary to abandon the simple directional models, and the conventional dichotomic 'large cycle - small cycle' conceptions, and to develop novel and more realistic conceptual representations of natural forest dynamics.

Kuuluvainen (2009) introduced a simple conceptual model that is based on distinguishing three main categories or modes of forest dynamics (see also Angelstam and Kuuluvainen 2004, Fig. 5): (1) Even-aged dynamics, driven by repeated stand-replacing disturbances, (2) Cohort dynamics, driven by partial disturbances, and (3) Gap dynamics, driven by tree mortality at fine scale. The prevalence of these modes of boreal forest dynamics in Fennoscandian research literature was reviewed by Kuuluvainen and Aakala (2011). They found that, contrary to the conventional view of dominance of severe stand-replacing disturbances in the boreal forest, gap, patch and partial disturbances were most commonly reported in the research literature. This highlights the importance of incorporating the variability of forest dynamics in conceptual models of forest dynamics (Kuuluvainen and Aakala 2011).

Figure 5 shows a comprehensive conceptual model of forest dynamics with three broad modes of dynamics and their relationships (Kuuluvainen 2009). In this model a forest can undergo directional succession after stand-replacing disturbance or remain in any one of the

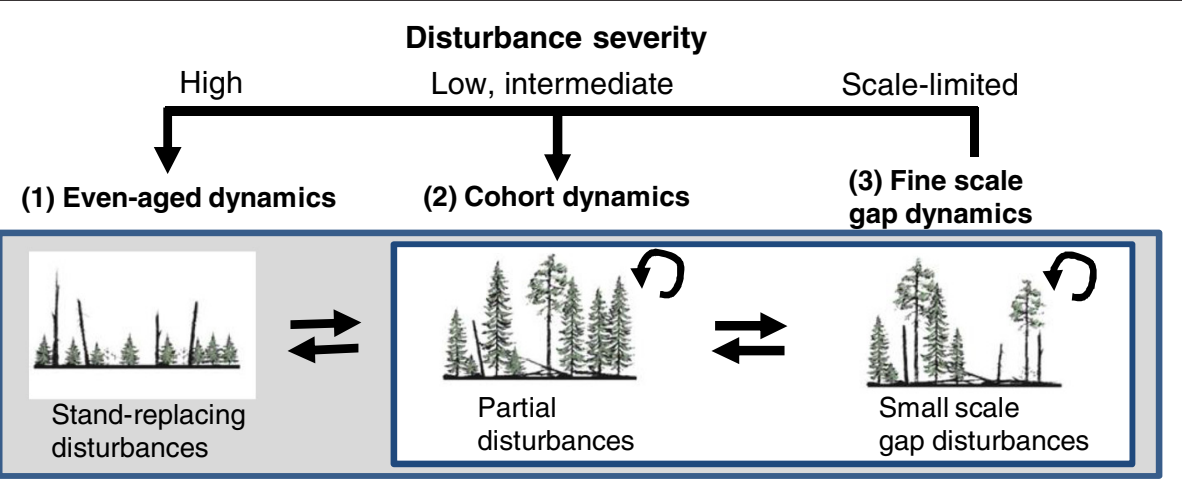

Fire, wind, insects

Competition, fire, wind, fungi, insects Senescence, fungi, insects

Directional succession

Fig. 5 Illustration of a "comprehensive conceptual model" of forest dynamics proposed by Kuuluvainen (2009), with three main categories or modes of forest dynamics, each of which is driven by a specific type of disturbance regime: (1) Even-aged dynamics, driven by repeated standreplacing disturbances, (2) Cohort dynamics, driven by repeated partial disturbances, and (3) Gap dynamics, driven by tree mortality at a fine scale (Fig. 5). In directional succession, a forest can go through these modes from even-aged dynamics after stand-replacing disturbance to cohort dynamics driven by partial disturbances to fine scale gap dynamics in old forests. On the other hand, each of the dynamics can also perpetuate if the driving disturbance regime type remains, or changed to another dynamics mode if the disturbance regime type changes 
three modes if the driving disturbance type is not changed. On the other hand, if the driving disturbance regime type changes transition to another forest dynamics mode is likely to occur (Fig. 5).

The bottom line in Fig. 5 represents the classical directional successional sequence, from stand-replacing disturbance to gap-dynamic old forest. Stand initiation and competition driven stem exclusion phases represent even-aged forest dynamics. The next step is a transition phase where the oldest tree age cohort starts to die due to competition and tree senescence-related insect and fungi damages, and non-stand-replacing windstorms or fires. As a result, the canopy gradually opens up and a cohort-type dynamics and tree age distribution and emerge. Finally, fine scale gap dynamics commences and a truly uneven-aged forest is developed in the latesuccessional phase (Fig. 5; Aakala et al. 2009).

Each of the three dynamics types, stand-replacing, cohort or small scale gap dynamics, can be maintained indefinitely if the driving disturbance regime type remains. For example, in continental areas of Canada, standreplacing fires with relatively short rotation cycles are common and maintain even-aged forest dynamics over extensive areas (Payette 1992). On the other hand, in areas where low-severity partial disturbances are common, cohort dynamics may dominate. This means that the forest is composed as a mix of older tree age classes (cohorts) surviving disturbances, and younger tree cohorts regenerating after disturbance events. Examples are provided by Fennoscandian Scots pine forests, which historically have been characterized by low-intensity surface fires (Lassila 1920). Due to the fire-resistance of large pine trees, repeated fires combined with other disturbances have historically created and maintained relatively open structurally complex stands consisting of multiple age cohorts of trees (Kuuluvainen and Aakala 2011). Finally, where major disturbances are absent for long periods of time, forest dynamics is driven by small scale gap disturbances related to senescence of trees (Kuuluvainen 1994). Examples are provided by nonpyrogenic old spruce forests in northern Fennoscandia (e.g. Aakala et al. 2009).
Key features of the conceptual model illustrated in Fig. 5 are coverage of a wide range of different kinds of forest dynamics and flexibility of state changes between modes of forest dynamics, which can take place when the driving disturbance regime type changes. For example, if an old-growth gap dynamic forest or younger even-aged forest is hit by partial disturbances (e.g. surface fires, medium-severity windstorms), a cohort type forest structure and dynamics is likely to result. On the other hand, a severe disturbance will re-initiate an even aged directional successional trajectory, but the details will depend on disturbance legacies and differential species availability at the time of the event. A comparison of the properties of the proposed model and the other models is presented in Table 1.

\section{Discussion}

Conceptual and visualized models of forest dynamics are powerful cognitive tools that can be used - or misused in communicating ecological ideas and knowledge in education and training of ecologists and foresters, and in forest management (McInerny et al. 2014). In many instances conceptual models can undoubtedly be more influential in directing human thinking and action than, for example, complicated mathematical and simulation models, which of course have their scientific and practical merits. Therefore, conceptual models, which are able to capture and demonstrate the essential features of forest dynamics, are indispensable for educational purposes, in setting goals and developing methods of forest conservation, restoration and ecosystem-based management (Bergeron et al. 2002; Kuuluvainen 2009; Kuuluvainen et al. 2015).

Regarding boreal forests, the conception of simple directional and deterministic forest development, starting from 'bare ground' and ending in static old-growth "climax" state, has by and large been the 'norm model', which is underlying the contemporary forest management paradigm and practices. However, the original reason why this conception received a dominant position was not the lack of realization that more complex forest structures and dynamics are naturally common, but

Table 1 Comparison of the properties of the different proposed conceptual models of forest dynamics and the comprehensive model proposed in this paper

\begin{tabular}{|c|c|c|c|c|}
\hline Conceptual model & Temporal representation & Spatial representation & Cross-scale interactions & $\begin{array}{l}\text { Transitions between modes } \\
\text { of forest dynamics }\end{array}$ \\
\hline Classical directional model & Directional & Unspecified (stand) & Not considered & Not considered \\
\hline Large vs. small cycle model & Directional and cyclic & Large and small scale & Not considered & Considered \\
\hline Mosaic cycle model & Cyclic & Patch/stand scale & Not considered & Not considered \\
\hline Panarchy & Cyclic & Multiple scales & Considered & Not considered \\
\hline Comprehensive model & Directional and cyclic & Multiple scales & Considered & Considered \\
\hline
\end{tabular}

References for the models: Classical directional model: Clements (1916), Begon et al. (2006). Large vs. small cycle model: Sirén (1955), Seymour et al. (2002). Mosaic cycle model: Remmert (1991). Panarchy: Holling (2001). Comprehensive model: Kuuluvainen (2009) 
rather the necessity to adopt a sufficiently simple conceptual model that could be used to organize rational forest management and for example to construct forest yield tables to predict forest growth. It was only afterwards that the conception of even-aged forest development was canonized as a 'natural' model of boreal forest dynamics. Hence, virtue was made out of necessity. As a result this history, the assumption that the directional model of even-aged forest development adequately represents intrinsic boreal forest dynamics has become deeply rooted in the mindset of forestry professionals and has therefore also profoundly influenced the adoption and development of silvicultural and forest management methods. What is worse, the adoption of this simplified conception has created "knowledge lock-ins" among professionals, which have seriously impeded the application of ecological knowledge in forest management (Puettmann et al. 2008; Moen et al. 2014).

For example, in Finland in the early $20^{\text {th }}$ century, silvicultural methods were outlined by leading forest authorities and researchers based on the premise that even-aged fully stocked stands represent the idealized 'normal forest'. In reality the motivation to promote this simple even-aged conceptual model was that it was a prerequisite for constructing yield tables that would also fit the adopted site type classification system developed by Cajander (1926). However, it was later admitted that such idealized evenaged 'normal forests' forests were extremely difficult to find in naturally dynamic forests (Ilvessalo 1937).

This example from Finland demonstrates more generally the case of boreal forests, where the adoption of the compartment-wise even-aged management system has been motivated by overly simplified ideas about forest structure and dynamics (Puettmann et al. 2008). Although it is currently widely recognized that forest dynamics are naturally more complex, including small scale gap and patch dynamics, and partial disturbances (Kuuluvainen and Aakala 2011; Taylor and Chen 2011), forest management continues to be predominantly grounded on the even-aged management approach. However, as expectations of ecological sustainability and provisioning of different ecosystem services from forests are growing (Burton et al. 2010), problems related to even-aged management are becoming more and more evident (e.g. Kuuluvainen et al. 2012). As a consequence, there is increasing interest in management approaches based on emulation of natural forest dynamics (Bergeron et al. 2002; Kuuluvainen et al. 2012), including continuous cover forestry utilizing single tree or group selection harvesting. Although such management approaches have traditionally been considered economically less profitable compared with even-aged management, this prejudgment has been questioned by recent research (Kuuluvainen et al. 2012; Rämö and Tahvonen 2014; Pukkala 2016).
Assumptions concerning forest dynamics are fundamentally important for setting reference forest conditions not only at stand scale but also at the landscape scale. This is because they affect what kind of landscape forest age structure and composition is considered as natural and desirable from the forest management, restoration or conservation point of view (Kuuluvainen et al. 2015). Theoretically, following the negative exponential distribution model of landscape forest age structure (Johnsson 1996), and assuming a random occurrence stand replacing disturbances on one percent of forest area with a 100 year fire cycle, $37 \%$ of the landscape would be covered by forest older than 100 years (Bergeron et al. 2002). However, in most cases this is not a realistic assumption about forest dynamics, because it ignores the prevalence of nonstand-replacing disturbances and associated forest dynamics, like gap and cohort dynamics. Compared to stand-replacing disturbances, these disturbance types support a continuous presence of much higher coverage of old forest in the landscape (Pennanen 2002; Kuuluvainen 2009; Kuuluvainen and Aakala 2011).

Thus the assumptions behind models of forest dynamics can drastically affect the setting of forest conservation and restoration targets and implementation of forest management. In particular, simplistic assumptions of the dominance of stand replacing disturbances and uncritical use of the negative exponential model of forest age distribution can lead to seriously biased estimation of reference landscape conditions, and hence need of restoration and conservations of different kinds of forest habitat types (e.g. Angelstam and Andersson 2001; Lõhmus et al. 2004). This in turn may easily lead to failure in attaining the goals of forest restoration or sustainable management, including maintenance of biodiversity and natural variability of ecosystem types.

\section{Conclusions}

Conceptual models of forest dynamics are powerful and indispensable cognitive tools for communicating ecological knowledge and ideas. They can be used - or misused - in developing methods and setting goals of forest conservation, restoration and sustainable management. In particular, excessively simple and hence misleading models of forest dynamics can lead to seriously biased assessment of targets for forest conservation, restoration and management both at local and landscape scales. This in turn can result in failure in achieving the desired state of forest ecosystems from the point of view of forest conservation, restoration or sustainable management.

Particularly in boreal forest management, forest dynamics has mostly been viewed through the lens of overly simple conceptual models of directional even-aged dynamics. However, the revealed variability in forest dynamics, and particularly the obvious prevalence of small scale and 
partial non-stand-replacing disturbances, call for more comprehensive models, which would adequately reflect the state of scientific understanding of forest dynamics. It is suggested that more comprehensive but relatively simple conceptual models, as that introduced by Kuuluvainen (2009) and discussed in this paper, are needed. Such models should be able to incorporate and visualize both long-term directional forest development as well as shorter-term cyclic forest dynamics of different kinds. Such models should also incorporate state changes and transitions from one dynamics type to another depending on changes in driving disturbance regime.

\section{Competing interests}

The author declares that he has no competing interests.

\section{Competing interests}

The author declares that he has no competing interests.

\section{Acknowledgements}

I wish to thank Petri Keto-Tokoi, Tuomas Aakala and three anonymous reviewers for insightful comments on the manuscript.

Received: 26 April 2016 Accepted: 30 June 2016

Published online: 05 August 2016

\section{References}

Aakala T, Kuuluvainen T, Wallenius T, Kauhanen H (2009) Contrasting patterns of tree mortality in late-successional Picea abies stands in two areas of northern Fennoscandia. J Veg Sci 20:1016-1026

Angelstam P, Andersson L (2001) Estimates of the needs for forest reserves in Sweden. Scand J For Res Suppl 3:38-51

Angelstam P. Kuuluvainen T (2004) Boreal forest disturbance regimes, successional dynamics and landscape structures - a European perspective. In: Angelstam P Dönz-Breuss M, Roberge J-M (eds) Targets and tools for the maintenance of forest biodiversity, vol 51, Ecol Bull., pp 117-136

Begon M, Townsend CR, Harper JL (2006) Ecology. From individuals to ecosystems. $4^{\text {th }}$ edition. Blackwell Publishing, USA, 738p

Belleau A, Leduc A, LeComte N, Bergeron Y (2011) Forest succession rate and pathways on different surface deposit types in the boreal forest of northwestern Quebec. Ecosci 18(4):329-340

Bengtsson J, Angelstam P, Elmqvist T, Emanuelsson U, Folke C, Ihse M, Moberg F, Nyström M (2003) Reserves, resilience and dynamic landscapes. Ambio 23(6): 389-396

Bergeron Y, Fenton NJ (2012) Boreal forests of eastern Canada revisited: old growth, nonfire disturbances, forest succession, and biodiversity. Botany 90:509-523

Bergeron Y, Leduc A, Harvey BD, Gauthier S (2002) Natural fire regime: a guide for sustainable management of the Canadian boreal forest. Silva Fenn 36:81-95

Bormann FH, Likens GE (1979) Pattern and process in a forested ecosystem. Springer, New York

Bunnell FL, Johnson F (eds) (1999) Policy and practices for biodiversity in managed forests, The living dance. UBC Press, Vancouver

Burton P (2013) Exploring complexity in boreal forests. In: Messier C, Puettmann KJ Coates KD (eds) Managing forests as complex adaptive systems. Building resilience to the challenge of global change. Routledge, London, pp 79-109

Burton PJ, Bergeron Y, Bogdanski BEC, Juday GP, Kuuluvainen T, McAfee BJ, Ogden A, Teplyakov VK, Alfaro Rl, Francis DA, Gauthier S, Hantula J (2010) Sustainability of boreal forests and forestry in a changing environment. In Mery G, Katila P, Galloway G, Alfaro Rl, Kanninen M, Lobovikov M, Varjo J (eds) Forests and Society - Responding to Global Drivers of Change. International Union of Forest Research Organizations (IUFRO), Vienna, Austria, pp 249-282

Cajander AK (1926) The theory of forest types. Acta For Fenn 29:1-108

Christensen NL Jr (2014) A historical perspective on forest succession and its relevance to ecosystem restoration and conservation practice in North America. For Ecol Manage 330:312-322
Clements FE (1916) Plant succession: An analysis of the development of vegetation. Garnegie institute of Washington Publications, No. 242. Washington, DC

Cowles HC (1911) The causes of vegetation cycles. Botanical Gazette 51:161-183

Donato DC, Campbell JL, Franklin JF (2012) Multiple successional pathways and precocity in forest development: can some forests be born complex? J Veg Sci 23:576-584

Drever CR, Peterson G, Messier C, Bergeron Y, Flannigan M (2006) Can forest management based on natural disturbances maintain ecological resilience? Can J For Res 36:2285-2299

Forcier LK (1975) Reproductive strategies in the co-occurrence of climax tree species. Science 189:808-810

Franklin JF, Spies TA, Van Pelt R, Carey AB, Thornburgh DA, Rae Berg D, Kindenmayer DB, Harmon ME, Keeton WS, Shaw DC, Bible K, Chen J (2002) Disturbances and structural development of natural forest ecosystems with silvicultural implications, using Douglas-fir forests as an example. Forest Ecology and Management 155:399-423

Fraver S, Jonsson BG, Jönsson M, Esseen P-A (2008) Demographies and disturbance history of a boreal old-growth Picea abies forest. J Veg Sci 19:789-798

Gauthier S, Vaillancourt M-A, Leduc A, De Grandpré L, Kneeshaw D, Morin H, Drapeau P, Bergeron Y (2009) Ecosystem management in the boreal forest. Les Presses de l'Université du Québec, Québec, p 568

Glenn-Lewin DC, van der Maarel E (1992) Patterns and processes of vegetation dynamics. In: Peet RK, Veblen TT (eds) Glenn-Lewin DC. Plant succession theory and application, Chapham \& Hall, pp 11-59

Gunderson LH, Holling CS (eds) (2002) Panarchy, Understanding transformations in human and natural systems. Island Press, Washington

Halme P, Allen KA, Aunins A, Bradshaw RHW, Brumelis G, Cada V, Clear JL, Eriksson A-M, Hannon $G$, Hyvärinen $E$, Ikauniece $S$, Iršènaitè $R$, Jonsson $B G$, Junninen K, Kareksela S, Komonen A, Kotiaho JS, Kouki J, Kuuluvainen T, Mazziotta A, Mönkkönen M, Nyholm K, Olden A, Shorohova E, Strange N, Toivanen T, Vanha-Majamaa I, Wallenius T, Ylisirniö A-L, Zin E (2013) Challenges of ecological restoration : Lessons from forests in northern Europe. Biol Cons 167:248-256

Holling CS (2001) Understanding the complexity of economic, ecological, and social systems. Ecosystems 4:390-405

Holling S, Meffe GK (1996) Command and control and the pathology of natural resource management. Cons Biol 10:328-37

Ilvessalo Y (1937) Growth of natural normal stands in central North-Suomi. Acta For Fenn 24(2):1-168

Johnson EA (1996) Fire and vegetation dynamics: studies from the North American boreal forest. Cambridge University Press, Cambridge, UK

Johnstone JF, Chapin SF III (2006) Effects of soil burn severity on post-fire tree recruitment in boreal forest. Ecosystems 9:14-31

Kneeshaw D, Bergeron Y, Kuuluvainen T (2011) Forest ecosystem structure and disturbance dynamics across the circimboreal forest. In: Millington AC, Blumler MB, Schickhoff U (eds) The Sage Handbook of Biogeography. Sage, Los Angeles, pp 263-280

Kuuluvainen T (1994) Gap disturbance, ground microtopography, and the regeneration dynamics of boreal coniferous forests in Finland: a review. Ann Zool Fenn 31:35-51

Kuuluvainen T (2009) Forest management and biodiversity conservation based on natural ecosystem dynamics in northern Europe: The complexity challenge. Ambio 38:309-315

Kuuluvainen T, Aakala T (2011) Natural forest dynamics in boreal Fennoscandia: a review and classification. Silva Fenn 45(5):823-841

Kuuluvainen T, Syrjänen K, Kalliola R (1998) Structure of a pristine Picea abies forest in northwestern Europe. J Veg Sci 9:563-574

Kuuluvainen T, Tahvonen O, Aakala T (2012) Even-aged and uneven-aged forest management in boreal Fennoscandia: a review. AMBIO. doi:10.1007/s13280012-0289-y

Kuuluvainen T, Bergeron Y, Coates KD (2015) Restoration and ecosystem-based management in the circumboreal forest: Background, challenges, and opportunities. In: Stanturf JA (ed.) Restoration of boreal and temperate forests. $2^{\text {nd }}$ edition, CRC Press

Kuuluvainen T, Wallenius TH, Kauhanen H, Aakala T, Mikkola K, Demidova N, Ogibin B (2014) Episodic, patchy disturbances characterize an old-growth Picea abies dominated forest landscape in northeastern Europe. For Ecol Manage 320:96-103

Landres PB, Morgan P. Swanson FJ (1999) Overview of the use of natural variability concepts in managing ecological systems. Ecol Appl 9:1179-1188 
Larsen AR, Chen HYH (2011) Multiple successional pathways of boreal forest stands in central Canada. Ecography 34:208-219

Lassila I (1920) Tutkimuksia mäntymetsien synnystä ja kehityksestä pohjoisen napapiirin pohjoispuolella. Acta For Fenn 14(3):95, in Finnish

Löhmus A, Kohv K, Palo A, Viilma K (2004) Loss of old-growth, and the minimum need for strictly protected forests in Estonia. Ecol Bull 51:401-411

McCarthy J (2001) Gap dynamics of forest trees: a review with particular attention to boreal forests. Environ Rev 9:1-59

Mclnerny GJ, Chen M, Freeman R, Gavaghan D, Mayer M, Rowland F, Spiegelhalter D, Stefaner M, Tessarolo G, Hortal J (2014) Information visualization for science and policy: engaging users and avoiding bias. Trends Ecol Evol 29(3):148-155

McIntosh RP (1981) Succession and ecological theory. In: West DC, Shugart HH Botkin DB (eds) Forest succession. Concepts and applications. Springer, New York, pp 10-23

Moen J, Rist L, Bishop K, Chapin FS III, Ellison D, Kuuluvainen T, Petersson H, Puettmann KJ, Rayner J, Warkentin IG, Bradshaw CJA (2014) Eye on the taiga: removing global policy impediments to safeguard the boreal forest. Cons Lett 7(4):408-418. doi:10.1111/conl.12098

Oliver CD (1980) Forest development in North America following major disturbances. For Ecol Manage 3:153-168. doi:10.1016/0378-1127(80)90013-4

Payette S (1992) Fire as a controlling process in the North American boreal forest. In: Leemans R, Bonan GB (eds) Shugart HH. New-York, Cambridge University Press, pp 144-169

Peet RK (1981) Changes in biomass and production during secondary forest succession. In: West et al. (eds) Forest succession. Springer-Verlag, New York

Pennanen J (2002) Forest age distribution under mixed-severity fire regimes - a simulation-based analysis for middle boreal Fennoscandia. Silva Fenn 36(1):2113-231

Pickett STA, White PS (eds) (1985) The ecology of natural disturbance and patch dynamics. Academic, New York

Pickett STA, Cadenasso ML, Meiners SJ (2008) Ever since Clements: from succession to vegetation dynamics and understanding to intervention. Appl Veg Sci 12:9-21

Podlaski R (2008) Dynamics of Central European near-natural Abies-Fagus forests: Does the mosaic-cycle provide an appropriate model. J Veg Sci 19:173-182

Puettmann KJ, Coates KD, Messier C (2008) A Critique of Silviculture: Managing For Complexity. Island Press, Washington, DC

Pukkala T (2016) Plenterwald, Dauerwald or clearcut? For Pol Econ 62:125-134

Rämö J, Tahvonen O (2014) Economics of harvesting uneven-aged forest stands in Fennoscandia. Scand J For Res 29:777-792

Remmert H (1991) The mosaic-cycle concept of ecosystems, Ecological Studies 85. Springer, Berlin

Schoener TW (2011) The newest synthesis: understanding the interplay of evolutionary and ecological dynamics. Science 331:426-429

Seymour RS, White AS, de Maynadier PG (2002) Natural disturbance regimes in northeastern North America: Evaluating silvicultural systems using natural scales and frequencies. For Ecol Manage 155:357-367

Shorohova E, Kuuluvainen T, Kangur A, Jogiste K (2009) Natural stand structures, disturbance regimes and successional dynamics in the Eurasian boreal forests: a review with special reference to Russian studies. Ann For Sci 66. 201.

Sirén G (1955) The development of spruce forest on raw humus sites and its ecology. Acta For Fenn 62:1-363

Sprugel DG, Bormann FH (1981) Natural disturbance and the steady state in high-altitude balsam fir forests. Science 211:390-393

Syrjänen K, Kalliola R, Puolasmaa A, Mattson J (1994) Landscape structure and forest dynamics in subcontinental Russian taiga. Ann Zool Fenn 31:19-34

Taylor AR, Chen HYH (2011) Multiple successional pathways of boreal forest stands in central Canada. Ecography 34:208-219

Turner MG, Dale VH (1998) Comparing large, infrequent disturbances: What have we learned? Ecosystems 1:493-496

Worrall JJ, Lee TD, Harrington TC (2005) Forest dynamics and agents that initiate and expand canopy gaps in Picea-Abies forests of Crawford Notch, New Hampshire, USA. J Ecol 93:178-190

\section{Submit your manuscript to a SpringerOpen ${ }^{\odot}$ journal and benefit from:}

- Convenient online submission

- Rigorous peer review

- Immediate publication on acceptance

- Open access: articles freely available online

- High visibility within the field

- Retaining the copyright to your article

Submit your next manuscript at $\gg$ springeropen.com 